論文

\title{
殺菌ランプの紫外線による負イオンの発生
}

\author{
正会員杉 本 賢* 馬込一男**
}

\section{Generation of Negative Air Ions by Ultraviolet Radiation from a Germicidal Lamp \\ Suguru Sugimoto (Member) Kazuo Magome}

(Consumer Products Research Laboratory, Mitsubishi Electric Co., Ltd.)

\begin{abstract}
Problems of air pollution have come to draw public attention of late. Concerning them, there have been many reports that negative air ions, which are negatively charged oxygen, water vapor or other fine particles, produce beneficical effects physiologically. When negative ions in air are reduced by air pollution, various ill effects are caused. In such cases, artificially produced negative ions are found useful.

The photoelectric threshold for gold is less than the energy of $2537 \AA$ radiation emitted from a germicidal lamp. Thus from the metal, negative air ions can be produced photoelectrically.

Both forward and backward photoemissions from a vacuum-deposited Au film under ultraviolet radiation of a germicidal lamp gave the maximum yield at about $60 \AA$ thickness. Further, the amount of air moved past the generator, the construction of the generator and the strength of electric field were determined experimeutally.

Relatively simple in construction this generator can be used to destroy bacteria and viruses in the air as well as generate ions.

\section{1. ま え がき}

空気中の正または負に带電した微粒子は，空気イオン として気象電気学, 生理学などの分野に打いてその性状 が研究されているが, 最近問題化している大気污染や人 工的環境の人体に対する影響とも関連して, 注目されて

一般に空気イオンは，その移動度によって大イオン $\left(0.004 \mathrm{~cm}^{2} / \mathrm{V} \cdot \mathrm{sec}\right.$ 以下), 間イオン $\left(0.004 \sim 0.04 \mathrm{~cm}^{2} /\right.$ $\mathrm{V} \cdot \mathrm{sec})$, 中イオン $\left(0.04 \sim 0.4 \mathrm{~cm}^{2} / \mathrm{V} \cdot \mathrm{sec}\right)$, 小イオン $\left(0.4 \mathrm{~cm}^{2} / \mathrm{V} \cdot \sec\right.$ 以上) に分類され***, このらら主とし て小イオンが生理学的効果を有する.すなわち, 小イオ ンのうら負イオンは鎮静的作用があるのに対して, 正イ

* 現在は相模工栄大学電気工学科

** 三菱電機船制作所

*** イオンの大きさの尺度として，イオンの動きやすさをとり，単位電 界中のイオンの移動速度, 寸なわ台移動度を使って表わす.

オンは刺激的作用を有するといわれている。大父中には 通常正負雨イオンが添同じ密度で存在するが，大気が 污染したり人工的環境に扔いては，このバランスがくず れて負イホンが減少する.ての結果, 人体に対して種々 の好ましくない影響が生じることが判明している1) 3). したがってこのような場合には，負イオンを人工的に 補給することが有用である。

殺菌ランプの紫外線（波長 $253.7 \mathrm{~nm}$ ) は, その光子

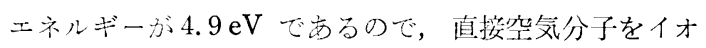
ン化することはできないが $\left(\mathrm{O}, \mathrm{N}, \mathrm{O}_{2}, \mathrm{~N}_{2}\right.$ のイオン化エ ホルギーは的でれ $13.6 \mathrm{eV}, 14.5 \mathrm{eV}, 12.2 \mathrm{eV}, 15.6$ $\mathrm{eV}$ である), 代事関数が $4.9 \mathrm{eV}$ よりさな物質表面に 入射すると, 光電效果により光電子が放出される. これ が空気中心酸素分子に付着すると, 負に带電した微粒子 すなわら負イオンが形成される，この原理を用いて負イ オンを人工的に発生させる場合問題亡なる点は, 光電子
\end{abstract} いる.

Vol. 54 No. 10 
放出の量子効率が良く, 空気中で少化の少ない光電面を 得ることである。また，発生した負イオンが空間電荷と なって後続のイオン発生を妨げたり，再結合によって消 減するのを防ぐことも必要である4).

このような点について実験検討し，負イオン発生装置 を試作したので，その結果を報告する。

\section{2. $\mathrm{Au}$ 薄膜からの光電子放出}

大気中で化学変化を受けにくい金属として Auを選ん

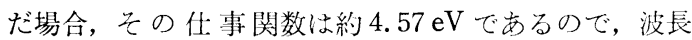
$253.7 \mathrm{~nm}$ の紫外線照射を受けると, 表面より光䉓子が 放出される.

そこでまず，真空中における $\mathrm{Au}$ 薄膜からの光電子放 出特性について調べてみた。 $\mathrm{Au}$ 薄膜光電面は真空蒸着 により形成することにし，十分に清浄化した顕微鏡用ス ライドガラスを基板として，Mo ボートから Au を加熱 蒸発させた。 その際，膜厚の制御は，モ二タ用ガラス板 上に形成される $\mathrm{Au}$ 薄膜の光透過率と膜厚との関係をあ らかじめくり返し反射干渉計を用いて求めて少き，蒸着 時にはモニタの光透過率を外部から測定して，任意の厚 さの $\mathrm{Au}$ 薄膜が得られるよらにした. これによって，真 架を破らずに $\mathrm{Au}$ 蒸着と光電子放出の測定を交互に行な い, 光電子放出の膜厚依存性を調べることができた.

光電子放出の测定は, 光源として $4 \mathrm{~W}$ 殺菌ランプを 真空蒸着装置のベルジャ一内に取り付忖, 光電流のコレ クターとしては Au 細線で格子状に作ったものを用い た.コレクターと試料光電面との距離は $10 \mathrm{~mm}$ であり, 試料光電面の殺菌線照度は $280 \mu \mathrm{W} / \mathrm{cm}^{2}$ である.コレク ターは $\mathrm{Au}$ 蒸着時には移動しておき, 蒸着㨁後に光電面 と対向させて光電流の飽和值を測定した，殺菌ランプの 照射は, 蒸着した $\mathrm{Au}$ 光電面側から（前方照射）之, 背 面のガラ大基板側から (後方照射) の二者について行な い, 後者の場合は, 紫外線がガラス基板を透過して Au 光電面に入射する必要上，透明石英ガラスを基板として 用いた・光電值の大きさはいずれも $25 \times 25 \mathrm{~mm}$ 大゙あ.

実験中，真空度は $2 \times 10^{-6}$ Torr 以下に保たれた。

以上の方法により, 測定した $\mathrm{Au}$ 薄膜からの光電子放 出の膜厚依存性を図1に示与。図から明らかなよらに 前方照约の場合法，膜厚の增加とともに光電子放出量も 増加し, 約 $60 \mathrm{~A}$ の厚さで極大值を示す。的や後やや減 少するが再びゆるやかに上昇して, 約 400 A の厚さで一。 定となる. Au 荧厚 $60 \AA$ A 付近のピークはみかけの仕事 関数の変化によるものであり, Au Bulk としての值は $200 \AA$ 付近からみられるが, 光電子放出のための溳電性 はこの厚㕛ではなお不足であり，400 A に至って十分な 導電性が得られる(このことの詳細は後に論議する). また，後方照射の場合は，やはり膜厚増加につ机て光電

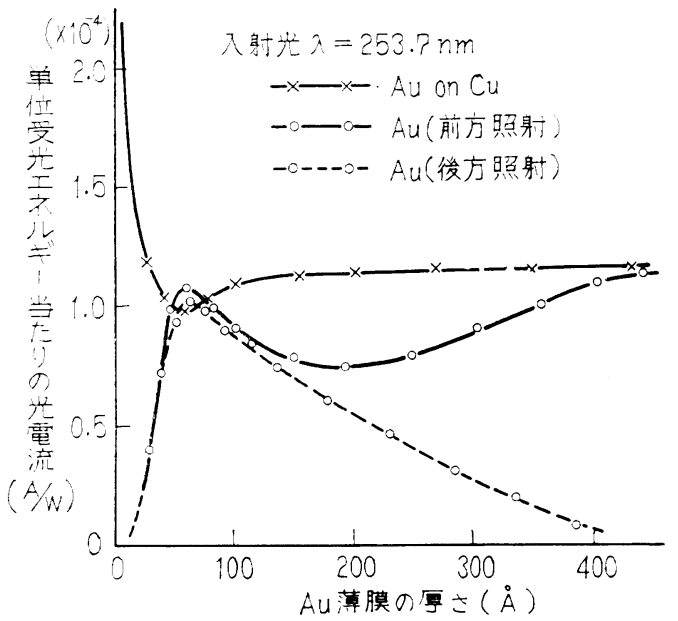

图 $1 \mathrm{Au}$ 薄瞙からの光電子放出膜厚依存性

子放出量も増加し，約 $60 \AA$ の厚さで最大值をとるが， 以後は単調に減少する。したがって，もし下地が十分に 導電性を有していれば，Au の膜厚が $200 \AA$ で Bulk の 值に相当する光電子放出が得られるはずである.

そこでまず，ガラス基板上に $\mathrm{Cu}$ を約 $500 \AA$ の厚さに 蒸着し, 続いてその上に Au を蒸着した場合の光電子放 出特性を測定してみた. 結果は図 1 内に示したように, $\mathrm{Cu}$ の仕事関数が $4.47 \mathrm{eV}$ で $\mathrm{Au}$ の值よりも小さいので, 最初は大きな光電子放出量が得られるが，Au蒸着とと もに減少する. そして数十丹の厚さの之き最小值を示し た後, $200 \AA ̊$ で Au Bulk の值に近い一定值に達する.

\section{3. 大気中における $\mathrm{Au}$ 面からの光電流特性}

前節で得られた結果から，Au 使用量の経済性を考慮 して，ガラス基板に $\mathrm{Cu}$ を $500 \AA$ 蒸着した上に $\mathrm{Au}$ を $200 \AA$ 蒸着したものと，Au だけを $60 \AA$ 蒸着したものに ついて，大父中に打汀る光電流特性を調べてみた.

すなわち，大父中において，これらの光電面を殺菌ラ ンフで照射した場合に得られる光電流を，真爯中と同様 な方法で測定した.この場合，コレクターと試料光電面 との距離は $10 \mathrm{~mm}$ であり, 試料光電面の殺菌線照度は $1,128 \mu \mathrm{w} / \mathrm{cm}^{2}$ である.

大父中に和ける光電面の少化を調べるためには, 光電 面作成淔後に初回測定を行なった後, 大気中に 2 週間放 置し，車ご同一条件で测定して初期值と比較した。これ

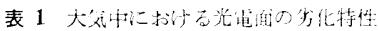

\begin{tabular}{|c|c|c|}
\hline \multirow{2}{*}{ 光 } & \multicolumn{2}{|c|}{ 単位受光エホルギー当たりの光電流 } \\
\hline & 初 & 2 週間挍 \\
\hline (I) $\mathrm{Au} 200 \hat{\mathrm{A}}$ on $\mathrm{Cu}$ & $0.39(\mu \mathrm{A} / \mathrm{W})$ & $0.36(\mu \mathrm{A} / \mathrm{W})$ \\
\hline (II) $\mathrm{Au} 60 \AA$ (前方盟射) & 0.11 & 0.08 \\
\hline 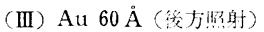 & 0.09 & 0.08 \\
\hline
\end{tabular}


らの結果を表 1 亿示す. これらの值を真空中の場合と比 較すると, 各光電面共 3 汀た小さい値になっている.こ れは大気中に和ける電子の平均自由行程が $10^{-5} \mathrm{~cm}$ 程度 でありコレクターと試料光電面との間の距離に比較し て非常に小さいこと, 执よび試料光電面に大父中の分子 が吸着して光電子放出を妨げることによるのであろら.

また，光電面（I）の光電流值は，光電面（II）の 4 倍強になって抢り，真空中の場合より差が大きいそその 理由は不明であるが，実用性を考光た場合，光電面（Ｉ） は $\mathrm{Au}$ の使用量も（II）の4倍であり，下地として Cu の蒸着が必要である. 一方，（II）の面積を4 倍沉す机 ば，Auの量や基板数も4倍となるが，得られる光電流 も4 倍になって（I）と同じになる.（II）と（III）と は汇とんど等しい光電流が得られ, 真空中の場合の比之 変わりない、しかし，(III）㳊基板として石英ガラスを 用いるので，このままでは非常に高価となって央用的で ない.

なお，劣化特性は，2週間後の単位受光エネルギー当 たりの光電流が光電面（I），（II），（III）についてそれ ぞれ初期值の $92.3 \%, 72.7 \%, 88.9 \%$ あり，光電面 （II）は（I），（III）に比較してわずか劣るが，（I），(III） については十分実用性があると考光られる。

\section{4. 負イオンの発生特性}

\section{1 負イオン発生装置の試作}

\subsection{1 光電面 (I) の適用}

光電面（I）を用いて負イオン発生装置を試作し，種 々の特性試験を行なった，発生装置の一例についてしる すと，顕微鏡用スライドガラスを基板として Cu打よび $\mathrm{Au}$ を蒸着した光電面を図 2 に示すように，両端が開 放したプラスチック製箱体内面に張りつわ，各々を電気 的に接続する。箱体の中央には, 光源として $10 \mathrm{~W}$ 殺菌 ランプを設置し，これを点灯して光電面に適当な負電生 を印加すると負イオンが発生する. てして，箱体の一方 の開放端から清浄空気を送風することにより，他端から

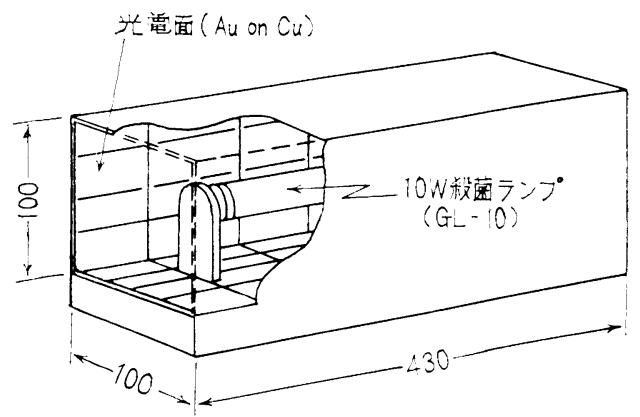

図 2 負イナン発生浆㯰\#1
発生した負イオンを筀間へ放出させるものである（この 装置を\#1 とする). 光電面に負電圧を印加するのは, 光電子や負イオンが光電面と再結合するのを防ぐためで ある。

\subsection{2 光電面 (II), (III) の応用}

後方から光照射を受ける光電面のうち, 最も直接的な ものは, 殺菌ランプの管壁に厚さ $60 \AA$ の $\mathrm{Au}$ 薄膜を蒸 着したものである。この場合は殺菌ランブの添添全放射 束が $\mathrm{Au}$ 光電面に入射与るので, 紫外線の利用率は最も 良く, したがって負イオンの発生量も多いことが期待さ れる. 厚さ $60 \AA$ の $\mathrm{Au}$ 薄膜導電性が不十分なため,

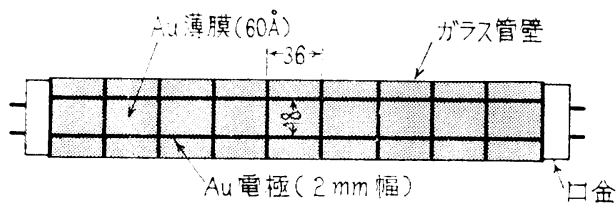

図 3 㐩菌ランプ管壁上の光電面の構造

図 3 に亦与ように格子状に厚く $\mathrm{Au}$ 電極 ( $\mathrm{Cu}$ でも可)を 蒸着し，これに負電压を印加して膜全体に至るようにし た.これらの電極の幅掞よび間隔は図 3 に示した值が最 適であった。な抗の場合，ランプ中央部に拈いて管壁 から距離 $5 \mathrm{~cm}$ に护る殺菌線照度は $887 \mu \mathrm{W} / \mathrm{cm}^{2}$ であ る*.このようなランプを前記と同様なプラスチック製 箱体の中央に設置して点灯し, 光電面電極に適当な負電 圧を印加して負イオンを発生させ，送風により空間へ放 出するようにした（装置 \#2）。ささらに，箱体内面に反射 率のよい $\mathrm{Al}$ 面を設けることにより上記ランプからの殺 菌線を反射させ，ランプ管壁上の光電面に対して前方照 射の効果をる付加してみた（\#3）. この場合は，一つの 光源就よび光電面で（II）と（III）の三者の作用を得る ことができるわけである。

\section{2 負イオン発生の諸特性}

これらの負イオン発生装置からの種々の条件に打ける 負イオン発生量を, 円筒形イオン濃度計により测定し た.この測定装置は，同心円筒形の二重電極間にイオン を含んだ空気を一定風速で吸引，電極間に直流電圧を 印加してイオンを捕集し, その際得られるイオン電流值 から, 空䒝 $1 \mathrm{cc}$ 中のイオン数（イオン濃度）を測定する ものである゙。測定にあたっては，小イオンだけを捕集 するようにした。これらの実験装置の概略を図 4 に示 +.

\subsection{1 負イオン発生量の経時変化}

負イオン発生装置\#1および させ場合の，負イオン発生量の経時変化を表 2 に示し

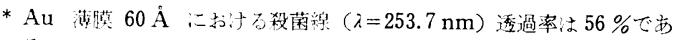
3 . 


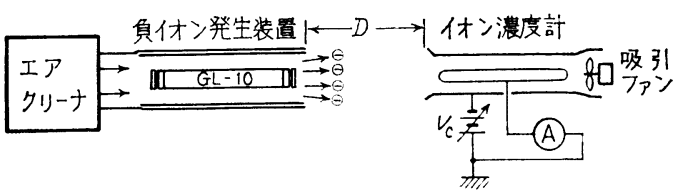

図 4 負イオン発生方よび㵋定装置の略図

表 2 経時変化の奉験条件

\begin{tabular}{|c|c|c|}
\hline \multirow{5}{*}{ 動作条件 } & 光 & $10 \mathrm{~W}$ 殺菌ランプ \\
\hline & \multirow{2}{*}{ 光電面面稍 } & $\# 1: 1530 \mathrm{~cm}^{2}$ \\
\hline & & $\# 2: 204 \mathrm{~cm}^{2}$ \\
\hline & 光電面印加電圧 & $\mathrm{V}_{\mathrm{Au}}=-200 \mathrm{~V}$ \\
\hline & イオン送出風速 & $\mathrm{v}=3,5 \mathrm{~m} / \mathrm{sec}$ \\
\hline \multirow{3}{*}{ 測定条件 } & 測 定 距 猚 & $\mathrm{D}=0.5 \mathrm{~m}$ \\
\hline & 捕 集 電 玗 & $V_{c}=-10 \mathrm{~V}$ \\
\hline & 吸引屈筮 & $\mathrm{Q}=2.5 \mathrm{l} / \mathrm{sec}$ \\
\hline
\end{tabular}

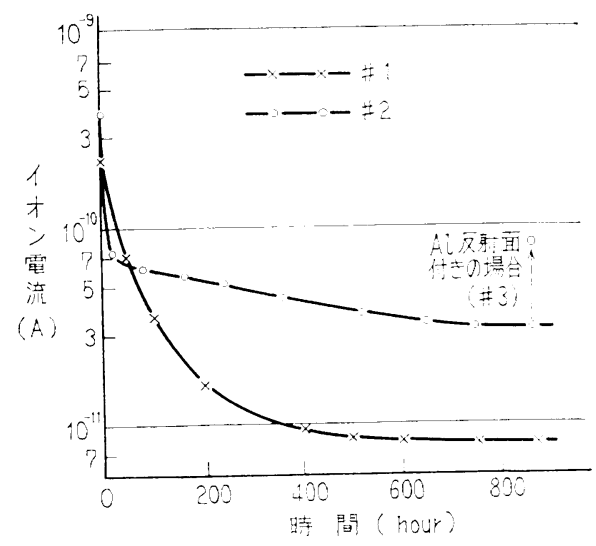

図5イナン発生量の経時変化

た条件で測定した，図 5 にその結果を示す、発生装置 \#1からの負イオン発生量は初めの間大きく減衰するが, しだいにゆるやかとなって，約 500 時間以後はきわめて わずかな減衰にとどょるようになる。聿2のほうは，初め の十数時間に急減少した後はゆるやかな減衰となり，数 百時間でほぼ一定值に落ち着く。これらの減衰は，空気 中の水分や歴埃が光電面に付着することによるものと考 学れる.\#2のほらが減衰が少ないのは, 光電面がラン ブ管壁に密着していて温度が $40^{\circ} \mathrm{C}$ 以上であるため. 水 分の吸着が少ないこと，委た円管状のため塵埃がたまり にくいことなどが原因であると思われる，860 時間後の イオン発生量を比較すると，\#1では捕集イオン電流 $7.8 \times 10^{-12} \mathrm{~A}$ ，イオン濃度 19,000 個/cc であるのに対し て，\#2では $3.2 \times 10^{-11} \mathrm{~A} ， 76,000$ 個/ $\mathrm{cc}$ であり，4 倍多 い值である.ささらに, 光電面印加電圧を $-150 \mathrm{~V}$ に (後述), $\mathrm{Al}$ 反射面を記けると（\#3)，罒中に示したよう に $8.0 \times 10^{-11} \mathrm{~A} ， 192,000$ 個/cc となり，\#1010 倍以 上に達する.

\subsection{2 光電面印加電圧と負イオン発生量の関係}

光放出された電子や発生した負イオンが, 光電面の近 くで空間電荷としてとどまって負イオンの発生を妨げた り, 光電面と再結合して消隇するのを防ぐため, 光電面 に法負電圧を印加する4)。この電圧と負イオン発生量と の関係を，イオン送出風速をパラメータとして測定し

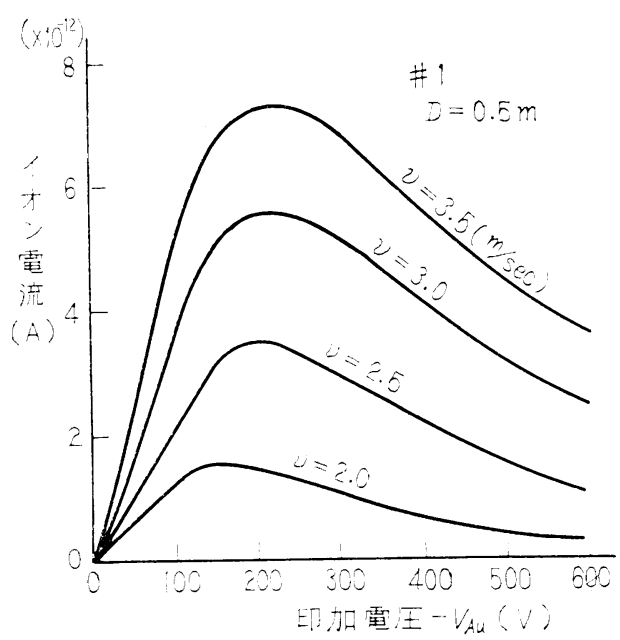

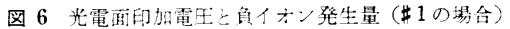

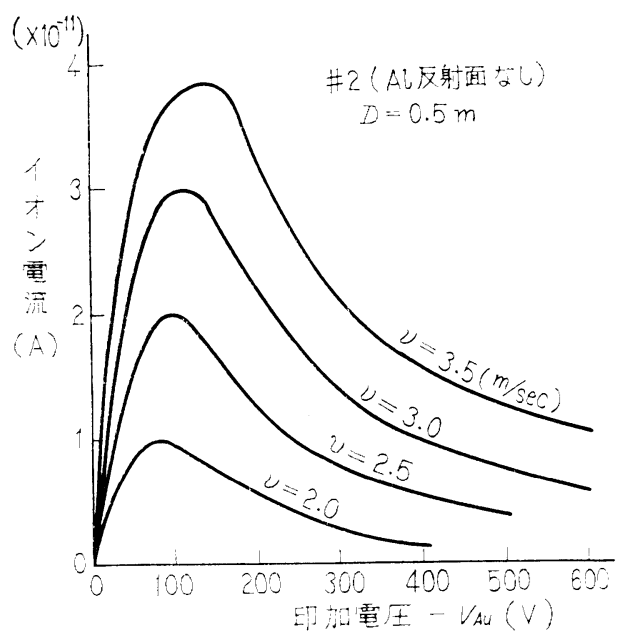

図 7 光電面印加電压上真イオン発生量（

た.その結果，図 6 战よび図 7 に示すように, 最初は印 加電圧 $V_{\mathrm{Au}}$ が負側飞增加するにつれて負イオン発生量 も増加するが，西る值 $V_{\mathrm{Au}} \max て ゙$ 最大值を示した後法減 少していく，そしてこの $V_{\mathrm{Au} \text { max }}$ は送出風速が大きい ほど負側にずれていく。このことは，実際の負イオン発 生量は $-V_{\mathrm{Au}}$ が大になるほど增加するが， $-V_{\mathrm{Au}}$ があ る值以上になると，負イオンの速度成分の送風による要 素より $V_{\mathrm{Au}}$ の電界による要素の汪らが大となり，電界 に沿って移動度の大きい負イオンは移動し，接地電位の 
箱体内面などに捕えられる割合が増加することを示して おり，このため発生装置外一送出される負イオンの量は 減少するものと考元られる，風速が大になれば，負イオ ンの移動速度の風速方向成分が增加するので, $-V_{\mathrm{Au} \text { max }}$ も增加することになる。発生装置 \#1の活らは，負イオ ンが金属筒内で発生するため電界の作用は小さく，\#2 のほうは，管軸から放射状に生ずる電界中で負イオンが 発生するため電界の作用は大きい, 測定の結果では, $V_{\text {Aumax }}$ の值に数 $10 \mathrm{~V}$ の差が生じている.

\section{4. $2.3 \mathrm{Al}$ 反射面の効果}

前記のように, 発生装置\#2の殺菌ランプの周囲に $\mathrm{Al}$ 反射面を設けることによって，負イオン発生量は 2.5 倍 になる.この場合, $\mathrm{Al}$ の仕事関数は $4.20 \mathrm{eV}$ であり, $253.7 \mathrm{~nm}$ で光電子放出の起こる可能性がある.したがっ て, $\mathrm{Al}$ 反射面からの負イオン発生も寄与しているかど らかを調べるために, $\mathrm{Al}$ 反射面汇も負電压 $V_{\mathrm{A} 1}$ を印加

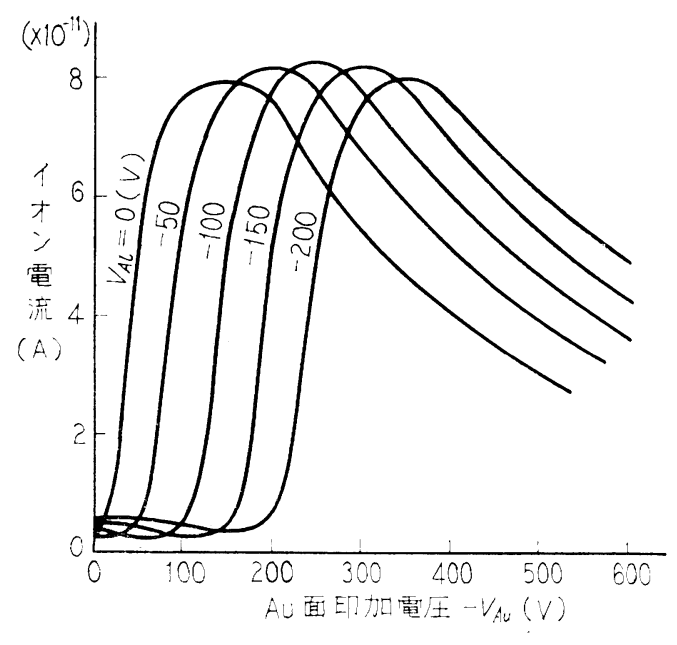

図 $8 \mathrm{Al}$ 反射面印加䉓压の効果

して, 種々の值における負イオン発生量を測定した。そ の結果, 図 8 に示すように, 負イオンの発生量は $V_{\mathrm{A} 1}-$ $V_{\mathrm{Au}}=150 \mathrm{~V}$ で最大となり，その值は $V_{\mathrm{A} 1}$ が，一100〜 $-150 \mathrm{~V}$ で最大となるが，その增加分は $V_{\mathrm{A} 1}=0$ のとき の数\%にすぎない、したがって $\mathrm{Al}$ 反射面の設圆による 負イオン発生量の大きな増加は, これにより反射された 紫外線がランプ管壁上の $\mathrm{Au}$ 光電面を前方から照射して 光電子を放出させ，負イオンを発生させることによるも のと判断される.

\subsection{4 発生装置からの距離と負イオン濃度}

発生装置から吹き出された負イオンは, 空間で拡散 し，正イオンや導体と再結合したり絶縁体に付着したり 乙て距離とともに減少していく.その一例を図 9 に示 した。

Vol. 54 No. 10

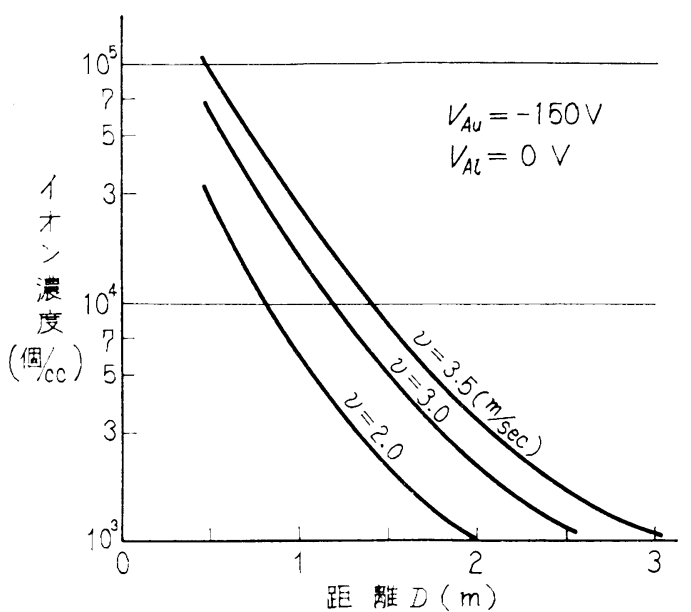

図 9 発生装置からの距雎と負イオン涨度

\section{5. あとがき}

自然界に打ける正常な負イオン濃度は数百ないし千個 /cc であり，海岸や山など空気の清浄な所ほど多い，都 会や工場地帯などの大気污染の激しい所, または空気の よごれた室内や人工的な空調を行なっている室内では, 負イオン濃度は 100 個/cc 以下にも減少( ${ }^{677)}$, 人体生理 に対して種々の悪影響を及汸す8)97。このような場合, 不足した負イオンを人工的隹補給すれば，これらの整害 を防ぐことが可能である. その一方法として, 本文で述 ベた殺菌ランプを利用した負イオン発生装置を, 空調装 置の清浄空気吹出し口部に設置すれば，比較的簡単な構 造でもって負イオンを補給できると同時に，Au 光電面 を透過した紫外線によって, 空気殺菌をも行ならことが でき, 保健衛生上好をしい効果が得られるものとい方よ 5 .

\section{文献}

(1) 木村, 谷口: 空気イオンの理論と実際

(2) I. A. M. K : Information of the 1st International Congress on the Air Ions. Oct. (1961) U.S.A

(3) 三浦豊彦: 労働科学 41 (1965) 269

(4) R. Nagy: Illum. Enging 56-2 (1961)

（5）原ほか：三菱電機技報 38 (1964) 1470

(6) 加藤敬二: 産業環境工学 2-12 (1962)

(7) 関川俊男: 同上 2-14 (1962)

(8) 安倍三史：同上 2-15 (1962)

(9) 市川重春：同上 2-16 (1962)

付 記

第 2 節の実験結果に対して, 理論的にはどうなるか考 
察してみる. いま, $\mathrm{Au}$ 薄膜内において, 入射光の強度 抢よび励起された光電子の放出確率が距離とともに指数 関数的に減少し, 薄膜内での光電子の多重反射はないも のと仮定する．前方照射の場合， $Q_{0}$ を入射 Photon Flux, $\alpha$ を光吸収定数, $L$ を光電子の平均自由行程 と すると, 表面から深さ $x$ の点での Photon Flux は $Q_{0} e^{-\alpha} x$ となり, $x$ と $x+d x$ の間で吸収される Flux は $\alpha Q_{0} e^{-\alpha x} d x$ で表わされる. Photon 1 個の吸収により 1 個の光電子が生ずるとすれば，この場合に生ずる光電子 の数は $\alpha Q_{0} e^{-\alpha x} d x$ に等しく，これらが表面に到達して 放出される確率は $e^{-x / L}$ に比例するから, 放出される光 電子の数は $\alpha Q e^{-\alpha x} \cdot e^{x / L} d x$ となる.したがって，厚さ $t$ の膜全体から放出される光電子の数 $n_{t}$ は次式で表わ される.

$$
n_{t}=Q_{0} \alpha \int_{0}^{t} e^{-\alpha x} \cdot e^{-x / L} d x
$$

入射 Photon Flux 当たりの光電流 $\left(I_{F}\right)$ で表わせば，

$$
\begin{aligned}
I_{F} & =e \alpha \int_{0}^{t} e^{-\alpha x} \cdot e^{-x / L} d x \\
& =\frac{e \alpha L}{1+\alpha L}\left(1-e^{-(1+\alpha L) / L \cdot t}\right)
\end{aligned}
$$

となる. 次に, 後方から光照射を受けた場合には, 光の 入射面から深さ $x$ の所で生じた光電子が，反対側の表面 洷達する確率は $e^{-(t-x) / L}$ に比例するから, 入射 Photon Flux 当たりの光電流 $I_{B}$ は,

$$
\begin{aligned}
I_{B} & =e \alpha \int_{0}^{t} e^{-\alpha} x \cdot e^{-(t-x) / L} d x \\
& =\frac{e \alpha L}{1-\alpha L}\left(e^{-\alpha t}-e^{-t / L}\right)
\end{aligned}
$$

となる ${ }^{1) 2)}$. そこで Au 薄膜について, $\lambda=253.7 \mathrm{~nm}$ の入

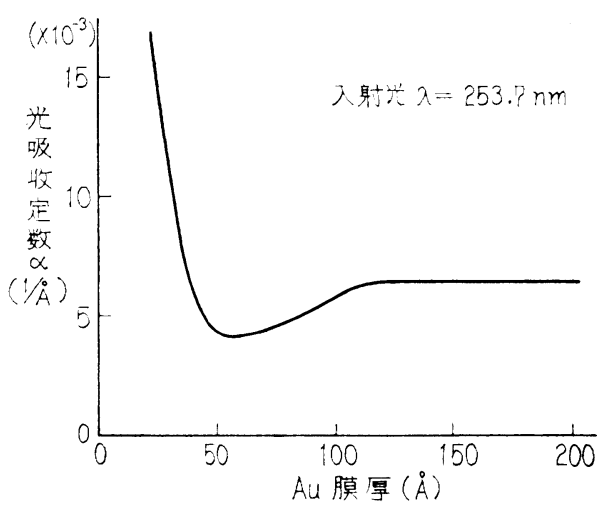

付図 $1 \mathrm{Au}$ 薄膜の光吸収定数の膜厚依存性

射光に対する (1) 式および (2) 式の計算值を求めてみる. 光吸収定数 $\alpha=(4 \pi / \lambda) \cdot k$ の中の $k$ の值は, 薄膜の場合 はBulk の值と異なり, 膜厚によって变化する. Krautkrämer のデータ ${ }^{3)}$ から， $\lambda=253.7 \mathrm{~nm}$ の入射光に対す
る $\alpha$ の膜厚依存性を求めると付図 1 が得られる。 た $L$ については, Sze et. al. の実験結果 ${ }^{4)}$ から $\lambda=$ $253.7 \mathrm{~nm}(h \nu=4.9 \mathrm{eV})$ に対して約 $75 \AA$ の值が得られ る. これらの数值を代入して求めた (1) 式扰よび (2) 式の 值をプロットしたものが付図 2 である.これらは, 図 1 の実験結果に見られるような明りょうな極大値を示し ていない。

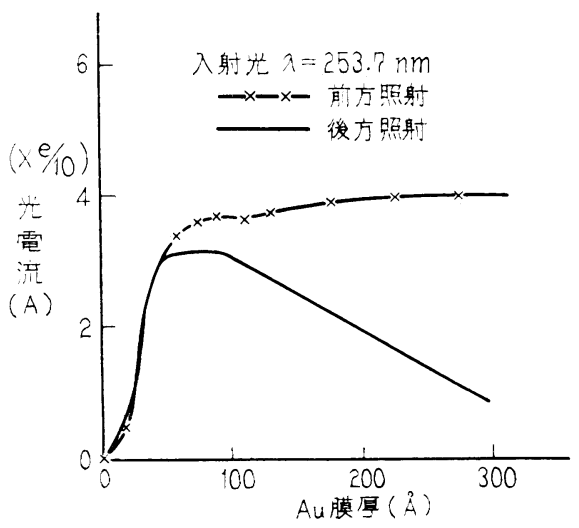

付図 $2 \mathrm{Au}$ 薄膜から光電子放出 (理論値)

Garron $^{225)}$ は, Au 薄膜の仕事関数も膜厚とともに変 化し，それはちょらど，前方照射の場合の光電子放出特 性と逆位相になることを見い出した。膜厚によって仕事 関数が変化するのは，ごく薄い膜厚範囲に打いては，膜 が特殊な構造 一Island Structure一をとり, 表面の電 子構造が変化するためと考光られる. 真空蒸着法で $\mathrm{Au}$ 薄膜を形成する場合, 最初から一様な膜が生じて成長す るのではなく，まず，はなればなれの粒状の核が生ず る.これらが成長するにつれて島状に集合し，しだいに すき間がふさがれて，平均膜厚約 $200 \AA ̊ 丿$ ですっかりつな がった膜になる（付図 3 ）。このような成長過程の途中
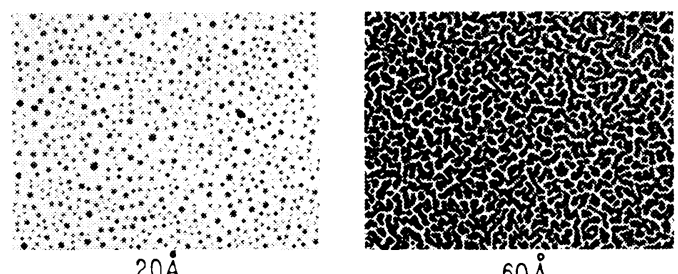

$60 \AA$

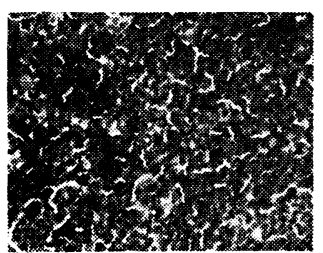

$140 \AA$

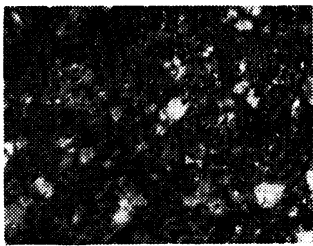

$210 \AA$

付図 $3 \mathrm{Au}$ 薄膜の成長過程 
で, 結晶表面にしみ出して表面二重層を形成している電 子が，各島状構造間で反発し 合って 自己減極作用を生 じ，仕事関数を減少させるものと思われる67)。これが 平均膜厚数 $10 \AA ̊ 丿$ の付近で最高に達する原因であろう。し たがって実験で得られた曲線の初めの上昇は， $\mathrm{Au} の$ 粒 子，島状構造の増加によるもので，それとともに仕事関 数が減少して $60 \AA$ さで極小となる結果, 光電子放出量は 極大值を示す. その後膜厚増加につれて仕事関数も増加 して光電子放出量は減少するが, 膜の導電性が増大して くるので, 光電子放出量は再び増加するようになる. $\mathrm{Au}$ 膜は約 $200 \AA$ の厚さで一様につながるのであるが，光電 子流が一定值に近つうくのは， $\mathrm{Au}$ 内の伝導電子の平均自 由行程に近い $400 \AA$ 付近である.

一方，後方から光照射を受けた場合は，やはり初めの 上昇は前記と同じで， $60 \AA$ 付近で仕事関数が最小とな って光電子放出量は最大值を示す。的後は膜厚増加と ともに, 励起された光電子の放出確率が減少するため, 光電子放出量も減少していくものと考えられる.

以上のよ5に, $\mathrm{Au}$ 薄膜からの光電子放出量が最も多 いのは，前方照射の場合に Au 膜厚が 400 Å以上になっ
たときでこれは Au Bulk の值であると考えられる。 しかしながら，Au表面の仕事関数は膜が一様につなが る厚さ $200 \AA ̊$ で Bulk の值となり，それ以上膜厚が増加 しても変わらない. 光電子放出量が増加するのは, 前記 のように導電性の増加によるものと思われる。また $\mathrm{Cu}$ 下地上に Au を蒸着した場合の $\mathrm{Au}$ 膜厚数 $10 \AA ̊ 丿$ に打る 最小值の出現については, Langmnir などによる異種原 子のイオン化吸着理論が模擬的に適用されよ れ ${ }^{6}$.

\section{付記の引用文献}

(1) C. R. Crowell et al: Phys Rev. 127 (1962) 2006

(2) R. Garron: La Machine-Outil Fransaise 85 (1963) 188

(3) J. Krautkrämer: Ann. Physik 32 (1938) 538

(4) 菅野卓雄：応物 33 (1964) 485

(5) R. Garron: Compt. rend. Acad. Sci. 255 [6]

（6）小林秋男：物性物理学講座 10

(7) R. Grarron: Compt. rend. Acad. Sci. 256 [11] （受付 1970 年 4 月 9 日，再受付同年 8 月 28 日） 